\title{
Relationship between Gentry and Plebs in the Land Disputes in Late Qing Dynasty: Study on the Basis of Archives of Huili in the Qing Dynasty
}

\author{
Fengye $\mathrm{Xu}{ }^{1}$ \\ ${ }^{1}$ School of History and Culture, Sichuan University, China
}

Keywords: Late Qing Dynasty, Farmland Dispute, Relationship between Gentry and Plebs.

\begin{abstract}
The land suing case between the gentry Yang Caiting and the peasant woman surnamed Longpu was very fully and accurately recorded in the Archives of Huili in the Qing Dynasty. The case shows that, in local power pattern of Huili in the late Qing Dynasty, lower gentry and common people formed an intertwined relationship around land, property, money and debt. County officer still had a certain authority, but lower gentry had been unable to keep a favorable position in competition with common people by only depending on its status and economic strength.
\end{abstract}

\section{Introduction}

The gentry who formerly studied the local politics in late Qing and Republican of China noticed that, from local troops commencing in the Jiaqing Period to secondary local troops climax emerging after the rising of the Taiping Heavenly Kingdom Army in the Xianfeng Period, various regions entered the era of local militarization. In the history course, gentry from place to place organized the public through mobilization and raised training fee by various means such as donation and collection of likin, and became dominant at practical operation level and obtained unprecedented power. Later, it was expansion of gentry power. I think, for the study on the relationship between gentry and plebs in local society in the late Qing Dynasty, it needs to go back to a specific space-time environment to understand the actual content of history. There are relatively complete rural grassroots administration and lawsuit archives preserved in Huili. By referring to these archives, it can help us to understand the relationship between gentry and plebs in local society in the late Qing Dynasty, so as to be a supplement of comprehensive study.

\section{Profile of Huili}

Huili is a multi-ethnic county. In the Qing Dynasty, it was "located at a remote place, with a circumference length of several thousand li". In the territory, "the Han people and the minority people often live together"[1]. However, the population density in Huili is only 7.5\% of that in eastern basin of Sichuan.

Archives of Huili were occasionally discovered in 1984, with a time span from the $18^{\text {th }}$ year of Qianlong Period (1753) to 1950. It has very rich archives of Guangxu Period, including two major categories. The first category is the official correspondence between Ningyuan Prefecture[2] and Huili Prefecture and between Yamen of Huili Prefecture and local gentry in Guangxu Period. The second category is the record about suing cases between gentry and plebs. The record about these disputes includes complaint, indictment, argument of gentry and plebs, judge of county officer, village convention and guarantee of the region where the case happened and petition of head of other organization.

In the archives of Guangxu Period, there was a suing case that happened between the gentry Yang Caiting and peasant woman surnamed Longpu and involved Kuzhu land officer Long Xingxiang and numerous tenants, local troops head and county Yamen officer and lasted for five years (from the $27^{\text {th }}$ 
year of Guangxu Period to the 32nd year of Guangxu Period), which fully shows the relationship between lower gentry and plebs in Huili in the late Qing Dynasty and provides rich original information for us to understand the relationship between gentry and plebs in local power pattern in the Late Qing Dynasty.

\section{Reason of Dispute and Mutual Suing Process}

In the $27^{\text {th }}$ year of Guangxu Period, the peasant woman surnamed Longpu pawned her farmland to the gentry Yang Caiting in succession for totally more than one thousand Liang and later, the peasant woman surnamed Longpu was poverty-stricken and asked Yang Caiting for relief, but Yang Caiting refused her", the peasant woman surnamed Longpu was taken to the court of Huili County for the reason of "robbing farmland". On the $29^{\text {th }}$ day of November in the Chinese lunar calendar of the same year, Yang Caiting also filed a lawsuit to peasant woman surnamed Longpu. In the indictment, he accused the peasant woman surnamed Longpu of "breach of faith and bullying" and said that, he was poor and had no farmland, there were many mulberry in his ancestral grave and on the $22^{\text {nd }}$ year of Guangxu Period, his father sold these mulberry and obtained several hundred Liang of silver. The peasant woman surnamed Longpu knew this event and borrowed one hundred and fifty Liang of silver from his father and used the 1/10 mu farmland at the dam center as pledge and promised to offer eight-Guanshuo and three-dou rice. Later, she pawned 2/10 mu farmland again and obtained the pawn price of four hundred and forty-three Liang, and she rented out her 5/10 mu farmland and obtained the pawn price of four hundred and forty-five Liang of silver. But after she obtained the money, she often refused to offer rice. Due to her wealth and awesome power, and due to death of his father and wedding of brothers, he had no time to accuse her. Unexpectedly, she forcibly took back the farmland that had been pawned to him[3], and attached the list of rice quantities owned to him by the peasant woman surnamed Longpu below. Thus, it became a mutual suing case.

One month after both sides accused each other, surnamed Li held a hearing for the two persons. In arraignments, peasant woman surnamed Longpu and Yang Caiting restated the reasons of accusing each other. In the county officer's opinion, this should be a simple farmland property dispute. He ordered the peasant woman surnamed Longpu "shall not collect any rent in the form of grain (in Dan) again for the property which has been rented and pawned, and shall find another buyer to sell and return money to Yang Caiting". The peasant woman surnamed Longpu accepted the judge in public. Four days later, the county officer ordered the head of Ji Village "to cooperate with Yang Caiting and direct the tenants to pay the rents in arrears to Yang Caiting. If the peasant woman surnamed Longpu obstructs again, the head of village shall report such situation to him and she shall be called to account and punished with due severity."Considering the possibility of the village head shielding the peasant woman surnamed Longpu, at the end of the letter, the county officer ordered "the village head shall not "shield due to close Personal Relationship." At this point, it had been December 28 of the $27^{\text {th }}$ year of Guangxu Period, and had reached the term of closing seal at the end of the year. However, after opening seal in the first month in the lunar calendar of the next year, Yang Caiting presented a written complaint. "as Yang Tuantou and the peasant woman surnamed Longpu are relatives, Yang Tuantou defies and disregards your order, instead instigates the peasant woman surnamed Longpu to collect the rice rent stored at the premises of tenants such as Liu Chengfa. He obviously bullies strangers and actually shows no respect to government official", said He. After receiving the written complaint, the county officer gave a written instruction of "conducting cross-examination in a rapid manner" However, at this point, it just encountered Huili county officer changing the term of office. After the new county officer surnamed Hu took office, on the $22^{\text {nd }}$ day of the $2^{\text {nd }}$ month in the lunar calendar, the peasant woman surnamed Longpu also presented a written complaint and said Yang Caiting himself didn't collect rice rent from tenants, instead made up a story and involved Yang Tuantou in the case.

But things had not gone smoothly. On the $13^{\text {rd }}$ day of the fifth month in the lunar calendar, the county officer had no choice but held a hearing on the case again. In the arraignments, the peasant woman surnamed Longpu requested that she should be bailed by Ye Hongfa and then she could rapidly sell her farmland property. In order to rapidly conclude the case, the county officer approved 
her request and imprisoned the guarantor and released the peasant woman surnamed Longpu. However, at this point, the leading yamen runner Sun Bing reported that, when he went to summon Yang Tuantou, who at first had been captured and unexpectedly plundered Lei Changsheng, Long Xingxiang, et al. who worked as a servant in Kuzhu Tusi Office, and they claimed that they would hand over such person only with an order. Therefore, Sun Bing requested the county officer to order the Kuzhu Tusi to hand over Long Xingxiang, et al. Two weeks later, the county officer ordered Kuzhu Tusi to rapidly "summon and hand over Yang Tuantou, Lei Changsheng and Long Xingxiang, et.al."For this, the peasant woman surnamed Longpu had a different saying. She said that, the case was originally accused by Yang Caiting based on fabricated evidence and he colluded with Yamen runner to concoct the fact of plunder, and said that, "today when I come to the city and wait for interrogation,Yamen runner Sun Bing detains me and ask me for money". Yang Tuantou said that, his money of over fifty thousand wen was taken away by the foreman surnamed Zhou in the prefectural yamen, and the person surnamed Long and the forman surnamed Zhou collude to detain him and resulted in that his wife died due to opiophagy. The conditions became more and more complex. On the 20th day of the 7th month in the lunar calendar, the county officer held a hearing on the case for the third time. During the trail, the peasant woman surnamed Longpu said that, the former county officer had judged that Yang Caiting should purchase her farmland property and so far the person surnamed Yang still made things difficult, but Yang Caiting said that, the former county officer surnamed Li had ordered the peasant woman surnamed Longpu to return the rent forcibly collected by her and sell her farmland property to repay the debt, and ordered Yang Tuantou to follow the matter, but Yang Tuantou destroyed the instrument and thus he came to accuse her again. For this, Yang Kaiwu, son of Yang Tuantou, said that, they were irrelevant to this case, but unfortunately were blackmailed by the foreman surnamed Zhou for more than 10 strings of copper cash and his father was caught and his mother was forced to die. However, the witness Sun Bing of the foreman surnamed Zhou said that, he didn't quarrel with the persons surnamed Yang and the mother of Yang Kaiwu died due to disease. He presented the letter from the shopkeeper Chen Xuantang of the shop where the case was handled, which proved that Yang Kaiwu made a false confession. Yang Caiting insisted on not buying and requested repayment at once, so the county officer ordered the peasant woman Longpu to invite the chiefs of Sanfei Bureau Li Yuanchun and Liu Guangchang as an inter-mediator to help her to sell her farmland property. After the trail, the pleb Kang Shuyou bailed the peasant woman Longpu to wait for hearing in the city.

For this, the peasant woman surnamed Longpu also presented a written complaint and said that, "Long Xingxiang was seriously ill and difficult to be present. I invited a person to ask him, but he died of illness at home. Now I have no person who can help me outside to raise silver and how can I conclude the case. In addition, I will sell my property to reply the debt, which would be relative to conscience, and is not conscience-shocking and ungrateful. I sadly consider in the midnight and beg your mercy to invite a guarantor to bail me out or detain me in the shop to wait for hearing, so that I can raise silver to repay my debt. In order to prevent disaster, I only can beg you". For this, the county officer replied that the deadline had expired and let her wait for being brought to trial. However, the peasant woman surnamed Longpu was not a person who was willing to wait, 25 days after she requested bail, the pleb Pu Jiheng said that, "I am a relative of the peasant woman surnamed Longpu and cannot bear to stand idly by, and I am willing to bail her to the shop for nursing her health. For the convenience, I will find a buyer to sell her farmland property on her behalf, and pay silver to Yang Caiting within a time limit, namely in the twelfth month of the lunar year, to solve the matter. If the peasant woman surnamed Longpu fails to repay the silver money or escapes and hides, I am voluntary to be held liable for compensation and be punished", and issued a letter of guarantee. Thus, the county officer agreed that the peasant woman surnamed Longpu was detained in the shop for recuperating her health.

On the $2^{\text {nd }}$ day of the 12thmonth of the lunar year, they escaped privately and hided in the home of Wei Tingjun and Zhang Douhua, fortunately they were caught by me". For this, the peasant woman surnamed Longpu presented a written complaint and said that "my son Long Xingqiang acts as the servant of Tuxi and refuse to be present under the instigation of adherents, I ask for mediation and my 
son prevents selling, and the tenants have rent in arrears for a long time and share out ill-gotten gains mutually, and entrap me into an unsettled law case, without any solutions," " Kuzu Tusi makes my son appear before the court, and ask for mediation for selling my property and orders the servant to detain me to Jiangzhou to find a buyer". Thus, the peasant woman surnamed Longpu passed the buck to the tenants and the servant of Tusi Office Long Xingxiang, who failed to appear before the court. Therefore, the county officer ordered servants to summon Long Xingxiang, tenant Liu Chengfa and plaintiff Yang Caiting to be present before the court. However, the leading servant Zhang Zhengming reported that, the servant of Tusi Office Long Xingxiang refused to be present before the court and requested the county officer to order Tusi surnamed Lu to make Long Xingxiang appear before the court. The county officer refused his request and asked him to summon and submit Long Xingqiang for trail in a rapid manner.

However, in the $7^{\text {th }}$ month and $8^{\text {th }}$ month of the $31^{\text {st }}$ year of Guangxu Period, Yang Caiting presented a written complaint respectively for twice and accused the servant Zhang Zhengming and $\mathrm{Zi}$ Litang of being in collusion with each other and entrapping. The case was tried again for three times. According to trial, we can know that, the peasant woman surnamed Longpu sold her farmland property to Kuzu Tusi Office and Tushe Zi Litang paid eight hundred Liang of silver to Yang Caiting, and Yang Caiting, handed over the lease, pawn agreement and pawn voucher to the servants and thus the case was closed.

\section{Power Relationship in the Dispute}

With regard to the case, the plaintiff surnamed Longpu is a widow and the defendant is her creditor Yang Caiting, a gentry. The woman surnamed Longpu borrowed silver from the man surnamed Yang by pledging her farmland property for several times, but failed to settle the rent interest as agreed. Later, the disagreement between the woman surnamed Longpu and Yang Caiting was that, Yang Caiting hoped the woman surnamed Longpu to repay silver for arrears and returned the rice rent forcibly collected by her. However the woman surnamed Longpu asked Yang Caiting to buy her farmland property so as to repay the debt. At first, the case was started by the woman surnamed Longpu accusing Yang Caiting of "robbing farmland". After the two persons accused each other, the woman surnamed Longpu expressed her will that she wanted Yang Caiting to buy out her farmland property to settle the debt for several times, but Yang Caiting insisted on not buying. Under such circumstances, the county officer thought that, "it is relative to transaction, and it is not suitable for enforcement", therefore, he judged that, the woman surnamed Longpu "shall not ask Yang Caiting to undertake to buy her farmland property, and shall find another to sell her farmland property to repay the debt". It is inferred according to the convention that, it is a simple economic dispute. However, the development of facts proves, it is not so simple to conclude the case. Here, the focus is strength contrast of both parties accusing each other.

At first, in terms of economic strength, it can be seen from the archives that, the two parties were associated with each other in the $22^{\text {nd }}$ year of Guangxu Period. Originally the woman surnamed Longpu borrowed 150 Liang of silver from Yang Caiting's father by pledging a 1/10 mu of farmland and successively pawned her farmland property to Yang Caiting. For the usage of silver borrowed by the woman surnamed Longpu, she herself said that, "it will be used for funeral arrangement". However, for economic condition of the gentry Yang Caiting, he himself said that, "brothers live apart and family financial situation is poverty-stricken". According to self-statements of both parties mutually accusing, we can draw a conclusion that both persons were not good in economic conditions. However, in fact it was not the case because it was impossible to support their vexatious suit for five years without strong economic strength. Next, in terms of social relationship, from beginning to end, we didn't see that Yang Caiting used his social relationship network. However, the woman surnamed Longpu was different, as a widow, traditional rules might have no too large constraints on her. Her son Long Xingxiang acted as a servant in Tusi Office and belonged to a bully. The servants dispatched by the county officer couldn't summon him to appear before court at all. Even though the county officer ordered Kuzhu Tusi to bring him before the court, it also possibly needed to assign several servants to bring him before the court. In fact, until the end of the case, we didn't see Long 
Xingxiang appearing before the court. However, the tenants surnamed Long, head of local troops and other widows went bail for the woman surnamed Longpu in succession, which indirectly shows that the people surnamed Long had deep-rooted power in local area.

Therefore, "the power that a man can exercise in his community depends on the resources, ability and qualification accumulated or mobilized by him" , in which "economic capital is an important source of well-being and social influence," and social capital and cultural are also equally important. The former is provided by social network, while the latter appears in the form of education qualification. Through the analysis of the case, we find that, the relatively influential persons are those who occupy economic capital and social capital and not necessarily those who have gentry status in traditional society. As in this case, when the lower gentry Yang Caiting encountered such a rival, in order to reduce losses, he could only make some concessions to agree that "the former and later interests will not be taken into account", the peasant woman surnamed Longpu "repay eight hundred Liang of silver to settle the matter after selling her farmland property" and he will "donate the rice rent of over 40 dan that shall be paid by each tenant in the year to the primary school as a fund ".

To sum up, according to the case, we can find many hidden subtle factors. It indirectly reflects that, in Huili in the late Qing Dynasty, gentry and plebs formed a state of entanglement around farmland, property, money and debt. The behaviors of lower gentry and pleb in the lawsuit and their psychologies reflect the daily picture of Huili rural economy in economic life. This is a picture different from the warm and harmonious one between gentry and plebs in traditional society and also different from the furious conflicting one between gentry and plebs in other regions in the late Qing Dynasty. Here, behind the seemingly placid rural life, disputes often happened, after the disputes were solved, everything was quiet again. In the dynamic and static alternation, the relationship between lower gentry and plebs in local society in Huili had changed. .

\section{References}

[1] Huili Prefecture Annals in Tongzhi Period, Volume X,Customs, Sichuan Prefecture and County Annals of Selection of China Local Chronicles, Volume 70, page no.s 245-246.

[2] Ningyuan Prefecture --In the early years of Shunzhi Period, it still was called Jianchangwei according to the system of the Ming Dynasty, which was the station of commander-in-chief of Jianchang Town. In the 6th year of Yongzheng Period (1728), it was renamed Ningyuan Prefecture, having jurisdiction over Huili Prefecture and setting up three counties Xichang, Mianning and Yanyuanand one hall Yuexi. (Pu Xiaorong: Modern Explanation on Administrative Territory Evolution and Jurisdictions of Sichuan, Sichuan People's Publishing House, 1986 version, page no. 436.)

[3]Huili Archives Storage, General Archives of Huili Prefecture Yamen in the Qing Dynasty, 1-1-125-13-1901. 